\title{
ASSESSMENT OF NUCLEAR DNA CONTENTS VARIATION AND THEIR RELATIONSHIP WITH FLOWERING IN CORN GENOTYPES
}

\author{
Gonul COMERTPAY I* $^{*}$ \\ ${ }^{1}$ Eastern Mediterranean Agricultural Research Institute, 01370, Dogankent, Yuregir, Adana, TURKEY \\ *Corresponding author: gonul.comertpay@gmail.com
}

Received: 08.11.2018

\begin{abstract}
Genome size variations are very helpful to provide an understanding of the diversification, evolution and ploidy screening of germplasm and investigate the aneuploidy, cell cycle kinetics, and reproductive pathways for the plants. It is observed that variation in the DNA content has a direct effect on the phenotype of a plant. Flowering time is considered one of the critical adaptation parameters for maize (Zea mays L.), and this study aimed to investigate the DNA content and its relationship with the flowering time in this crop. A total of 19 inbred lines and three hybrids adapted to temperate and tropical regions with early, late and very late flowering were used as plant material. Their DNA content was determined using flow cytometry, and Vicia sativa as standard for the comparison of DNA content. The DNA content of the studied material of corn ranged from $5.508 \mathrm{pg}$ to $6.285 \mathrm{pg}$, with an average value of $5.817 \mathrm{pg}$. The Highest DNA content was determined in the Tzi8 inbred line belonging to a group of very late flowering. A highly significant and positive correlation was found between DNA content and flowering time, which was confirmed with a regression analysis. The results of the study revealed that increasing the DNA content resulted in delayed flowering, and inbred lines adapted to tropical regions had a higher DNA content.
\end{abstract}

Key words: Corn, correlation, DNA content, flowering time

\section{INTRODUCTION}

The DNA content of any organism offers valuable data on the various foundational aspects of its biology and different characteristics, which can be practically utilized for different purposes (Janoušek et al., 2012; Leitch and Leitch, 2012). It is universally proved that a significant level of variation is present in the nuclear DNA content or genome size within plants. It is believed that eukaryotes contain more than 200,000-fold and plants contain more than 1,000-fold variation (Knight et al., 2005). DNA content varies from species to species, and variations have been observed even between very closely related species. Such differences have been associated with the various types of repetitive sequences, including transposable elements (TEs) (Kidwell and Lisch, 2002), which comprise a large fraction of genome (Nadeem et al., 2017; Wessler, 2006). Variations in the amount of TEs could be interpreted as differential amplification of TEs between lineages. One of the most striking examples is considered to be maize with a DNA content that doubled over a few million years due to burst of retrotransposon transposition (SanMiguel et al., 1996). This strengthens the hypothesis that genome can only increase in size (Bennetzen and Kellogg, 1997). Now it is fully established that increased DNA content through the amplification of various repeated sequences is a reversible illegitimate recombination process (Devos et al., 2002). Various phylogenetic approaches reveal that an increase/decrease in the DNA content occurs in any organism at the time of its evolution (Ma et al., 2004; Wendel et al., 2002).

$\mathrm{C}$-value, representing the number of base pairs or picograms of DNA existing in a gametic nucleus or unreplicated haploid (Bai et al., 2012), is considered one of the most important criteria upon which DNA content is characterized. It Greilhuber et al. (2005) comprehensively described $\mathrm{C}$-value and presented it to be equal to the haploid DNA content. A fair number of studies have been conducted to explore the C-value data for various organisms. For example, since 1976, Bennett and his team have published nine compilations of C-value data (Bennett and Leitch, 2011; Zonneveld et al., 2005). After 1997, further efforts were made to access data much easily, and the Angiosperm DNA C-values Database was used to share this data (Bennett and Leitch, 1997). As a result of various studies all over the world, the $\mathrm{C}$-values of 7,058 plant species have been reported (Bennett and Leitch, 2011). This database mainly summarizes taxonomic, statistical, cytological, technical and bibliographic information.

Population-level analysis facilitates selection on the basis of DNA content (Petrov, 2001); however, most 
analyses exploring the evolutionary process based on DNA content have been conducted on an inter-species scale. DNA content has been studied more efficiently for the genus Zea compared to other genera within the plant kingdom. Zea contains the species Zea mays, which is represented by domesticated subspecies maize (Zea mays ssp. mays) and two prominent wild subspecies, Zea mays ssp. mexicana and Zea mays ssp. parviglumis (Díez et al., 2013). Greilhuber and Leitch (2013) suggested that variations in the percentage of heterochromatin and absence or presence of B chromosomes (Bs) were the two main factors for DNA content variation in maize. Heterochromatic knobs, varying in size and number, play an effective role in 2C variations (Fourastié et al., 2018). Previous studies revealed a positive correlation between DNA content, heterochromatin (\%), and number of knobs (Realini et al., 2016). DNA C-values have been successfully used by various researchers to provide an understanding of the evolution, ecology, developmental, cellular and molecular biology of plants (Bennett et al., 2000; Bennett and Leitch, 2011; Leitch and Bennett, 2007). However, there the debate concerning whether DNA content varies within all species continues (Knight et al., 2005), but only little doubt is present about the DNA content variations within Zea mays (Díez et al., 2013). It is observed that DNA content varies by at least $30 \%$ in accessions containing both inbred lines and open pollinated landraces of this crop (Díez et al., 2012).

There are two types of phenomenon that result in a strong interaction between phenotype and DNA content (Möller, 2018): physical phenomenon, which depends on the physical properties of DNA, affecting the phenotype through effects on cell volume and cell replication time, and regulatory phenomenon, which refers to the effects of repetitive DNA sequences on the regulation of gene expression (Meagher and Vassiliadis, 2005). Previous studies confirmed that increased DNA content rather than the parental midpoint is related with the lack of heterosis (Rayburn et al., 1993), and DNA content is negatively correlated with growth and yield parameters by increasing the growth period and leading to a longer life cycle in maize (Rayburn et al., 1994). It is also believed that some of the variations in the maize DNA content may be associated with the B chromosomes (Poggio et al., 1998); however, there is only limited evidence implicating repetitive DNA (Meagher and Vassiliadis, 2005). Rayburn et al. (1994) stated that early-flowering maize accessions reflected a correlated response of reduced DNA content. The results of Rayburn et al. (1994) clearly indicate a causal relationship between plant growth and DNA content. Other studies presented a negative correlation between altitude/latitude and maize DNA content, suggesting that DNA content could be related with fast growth and early flowering in areas with shorter growing periods (Bennett and Leitch, 2005; Rayburn et al., 1994). Furthermore, some scientists stated that DNA content was positively associated with various physiological features, such as flowering interval, and cold and freeze tolerance (Greilhuber and Leitch, 2013; Poggio et al., 1998; Realini et al., 2016). For soybean, the DNA content reflected a positive correlation with growth habit (Graham et al., 1994), while Chung et al. (1998) found a very positive correlation between DNA content and leaf and seed size of soybean. Minelli et al. (1996) reported highly significant and positive correlations in Vicia faba for DNA content, embryo size, and seed size, and there were also negative correlations of DNA content with various adult plant traits; e.g., plant height and fresh weight. DNA $\mathrm{C}$-values have been successfully utilized to investigate the evolution, ecology, development, physiology and molecular biology of plants (Bennett et al., 2000; Bennett and Leitch, 2005, 2011; Leitch and Bennett, 2007). Recently, there has been a growing interest in the relationship between DNA content and seed mass (Beaulieu et al., 2007), and between DNA content and environment ( $\mathrm{Li}$ et al., 2018). The current study aimed to determine the DNA content of maize lines and investigate its relationship with flowering time.

\section{MATERIALS AND METHODS}

\section{Plant materials}

A total of 19 maize inbred lines and three hybrids belonging to different maturity zones and different groups of flowering time (early, late and very late) were used as plant material in this study (Table 1). The flowering data of inbred and hybrids were obtained from experiments conducted over three years under first-crop conditions in the experimental field of the East-Mediterranean Agricultural Research Institute in Adana, Turkey

\section{Estimation of DNA content}

For the estimation of nuclear DNA content, a total of 105 samples, 21 genotypes with five repetitions for each genotype, were analyzed. The plants from the samples of each line were randomly selected. Fresh healthy leaf tissues from three- to five-week-old seedlings were collected in Adana and transferred to the Plant Genetics and Cytogenetics Laboratory of Agricultural Faculty of Namik Kemal University located in Tekirdag, Turkey. The materials were kept at $4^{\circ} \mathrm{C}$ between two layers of moisture filter paper placed in a disposable Petri dish until analysis. Approximately $40 \mathrm{mg}$ of leaf tissue from the maize plants and $20 \mathrm{mg}$ of leaf tissue from Vicia sativa (cultivar Orak-Efe) as internal standard were chopped at the same time to prepare samples. The samples were prepared using the 'CyStain PI absolute P' nuclei extraction and a staining kit (Partec GmbH, Munster) according to the manufacturer's instructions. The absolute DNA content of the maize plants was calculated based on the ratios of the $\mathrm{G} 1$ peak means of the sample and the reference standard. 
Table 1. Nuclear DNA content and its standard deviation, maturity zones, season type, and days to flowering of genotypes.

\begin{tabular}{|c|c|c|c|c|c|c|}
\hline No & Name & $\begin{array}{l}\text { Status of } \\
\text { genotype }\end{array}$ & Maturity Zone & Season Type & $\begin{array}{c}\text { Mean 2C value } \\
(\mathrm{pg})\end{array}$ & $\begin{array}{c}\text { Days to } \\
\text { Flowering }\end{array}$ \\
\hline 1 & Lp5 & Inbred line & Temperate & Early & $5.726 \pm 0.079$ & 52 \\
\hline 2 & PHDD6 & Inbred line & Temperate & Early & $5.720 \pm 0.033$ & 50 \\
\hline 3 & $3 I B Z 2$ & Inbred line & Temperate & Early & $5.508 \pm 0.094$ & 53 \\
\hline 4 & PHFA5 & Inbred line & Temperate & Early & $5.576 \pm 0.172$ & 54 \\
\hline 5 & PHGG7 & Inbred line & Temperate & Early & $5.660 \pm 0.170$ & 54 \\
\hline 6 & PHKM5 & Inbred line & Temperate & Early & $5.704 \pm 0.040$ & 54 \\
\hline 7 & OQ403 & Inbred line & Temperate & Early & $5.610 \pm 0.125$ & 55 \\
\hline 8 & PHAA0 & Inbred line & Temperate & Early & $5.748 \pm 0.066$ & 55 \\
\hline 9 & PHM81 & Inbred line & Temperate & Early & $5.848 \pm 0.147$ & 56 \\
\hline & & & \multicolumn{2}{|c|}{ Early flowering group Mean } & $5.677 * * * \pm 0.025 \mathrm{C}$ & $53.67 \pm 1.803$ \\
\hline 10 & DKC6590 & Hybrid & Temperate & Late & $5.734 \pm 0.121$ & 63 \\
\hline 11 & KEBEOS & Hybrid & Temperate & Late & $5.892 \pm 0.056$ & 65 \\
\hline 12 & P2088 & Hybrid & Temperate & Late & $5.896 \pm 0.075$ & 65 \\
\hline 13 & $\mathrm{BCC} 03$ & Inbred line & Temperate & Late & $5.948 \pm 0.213$ & 69 \\
\hline 14 & LH159 & Inbred line & Temperate & Late & $5.680 \pm 0.094$ & 70 \\
\hline 15 & LH208 & Inbred line & Temperate & Late & $5.702 \pm 0.069$ & 70 \\
\hline 16 & LH212Ht & Inbred line & Temperate & Late & $5.886 \pm 0.064$ & 72 \\
\hline \multirow[t]{2}{*}{17} & LH156 & Inbred line & Temperate & Late & $5.940 \pm 0.056$ & 73 \\
\hline & & & \multicolumn{2}{|c|}{ Late flowering group Mean } & $5.835 * * * \pm 0.027 \mathrm{~B}$ & $68.38 \pm 3.623$ \\
\hline 18 & Tx303 & Inbred line & Tropical & Very late & $5.818 \pm 0.038$ & 80 \\
\hline 19 & $\mathrm{NC} 304$ & Inbred line & Tropical & Very late & $5.902 \pm 0.183$ & 80 \\
\hline 20 & Tzi15 & Inbred line & Tropical & Very late & $6.143 \pm 0.130$ & 85 \\
\hline 21 & Tzi8 & Inbred line & Tropical & Very late & $6.285 \pm 0.252$ & 85 \\
\hline \multirow[t]{7}{*}{22} & Tx601 & Inbred line & Tropical & Very late & $6.224 \pm 0.190$ & 90 \\
\hline & & & \multicolumn{2}{|c|}{ Very late flowering group Mean } & $6.062 * * * \pm 0.035 \mathrm{~A}$ & $84.00 \pm 4.183$ \\
\hline & & & & Overall Mean & $5.817 \pm 0.221$ & $65.91 \pm 12.386$ \\
\hline & & & & Median & 5.790 & \\
\hline & & & & Mode & 5.850 & \\
\hline & & & & LSD $_{0.001}$ & 0.738 & \\
\hline & & & Coeff & ent of variance & 2.075 & \\
\hline
\end{tabular}

$* * *$ Significant difference at a $\mathrm{P}$ value of 0.001

\section{Statistical analysis}

The analysis of the variation of nuclear DNA content values among the genotypes grouped by flowering time (early, late and very late) was performed using a standard one-way ANOVA with a generalized linear model. The comparison between the groups was undertaken by the least significant difference test if the F-test produced significant results at $\mathrm{P}<0.05$. Pearson's correlation coefficient was calculated to investigate the correlation between nuclear DNA content and flowering time. To analyze the variation more comprehensively, a regression analysis of DNA content and flowering time was also performed. All statistical analyses were conducted using JMP statistical package ver. 7 (SAS Institute, Cary, NC, USA).

\section{RESULTS AND DISCUSSION}

\section{Results}

Twenty-one genotypes of maize with five repetitions were analyzed for nuclear DNA content variation. Clearly defined histograms for various genotypes were obtained from the flow cytometry analysis of the DNA content analysis (Figure 1). The mean nuclear DNA content and flowering time of the genotypes are presented in Table 1. The studied material reflected a good level of variation in terms of flowering time and grouped as early, late, and very late according to this parameter. The result of variance analysis showed that the mean DNA values obtained from the maize genotypes significantly differed with a $\mathrm{P}$ value of 0.0001 . In the early flowering group, PHDD6 was the inbred line having the lowest number of days (50) to flowering, while PHM81 had the highest DNA content $(5.848 \pm 0.147 \mathrm{pg})$. In this group, the average number of days to flowering was 53.67, and the mean DNA content was $5.677 \mathrm{pg}$. In the late flowering group, which containing both inbred lines and hybrids of maize, DKC6590 had the lowest number of days (63) to flowering, BCC03 had the highest DNA content (5.948 \pm $0.213 \mathrm{pg}$ ), and the mean DNA content and average number of days to flowering were $5.835 \mathrm{pg}$ and 68.38 days, respectively. For the very late flowering group comprising inbred lines of tropical origin only, Tx601 had the highest number of days (90) to flowering, and the highest DNA content $(6.285 \pm 0.190 \mathrm{pg})$ was obtained from the Tzi8 inbred line. The average DNA content for the early, late 
and very late flowering groups was $5.677 \mathrm{pg}, 5.835 \mathrm{pg}$ and $6.062 \mathrm{pg}$, respectively, and the overall averages of the three groups in terms of DNA content and number of days to flowering were calculated as $5.817 \pm 0.221 \mathrm{pg}$ and 65.91 days, respectively. The distribution frequency of DNA content is presented in Figure 2.
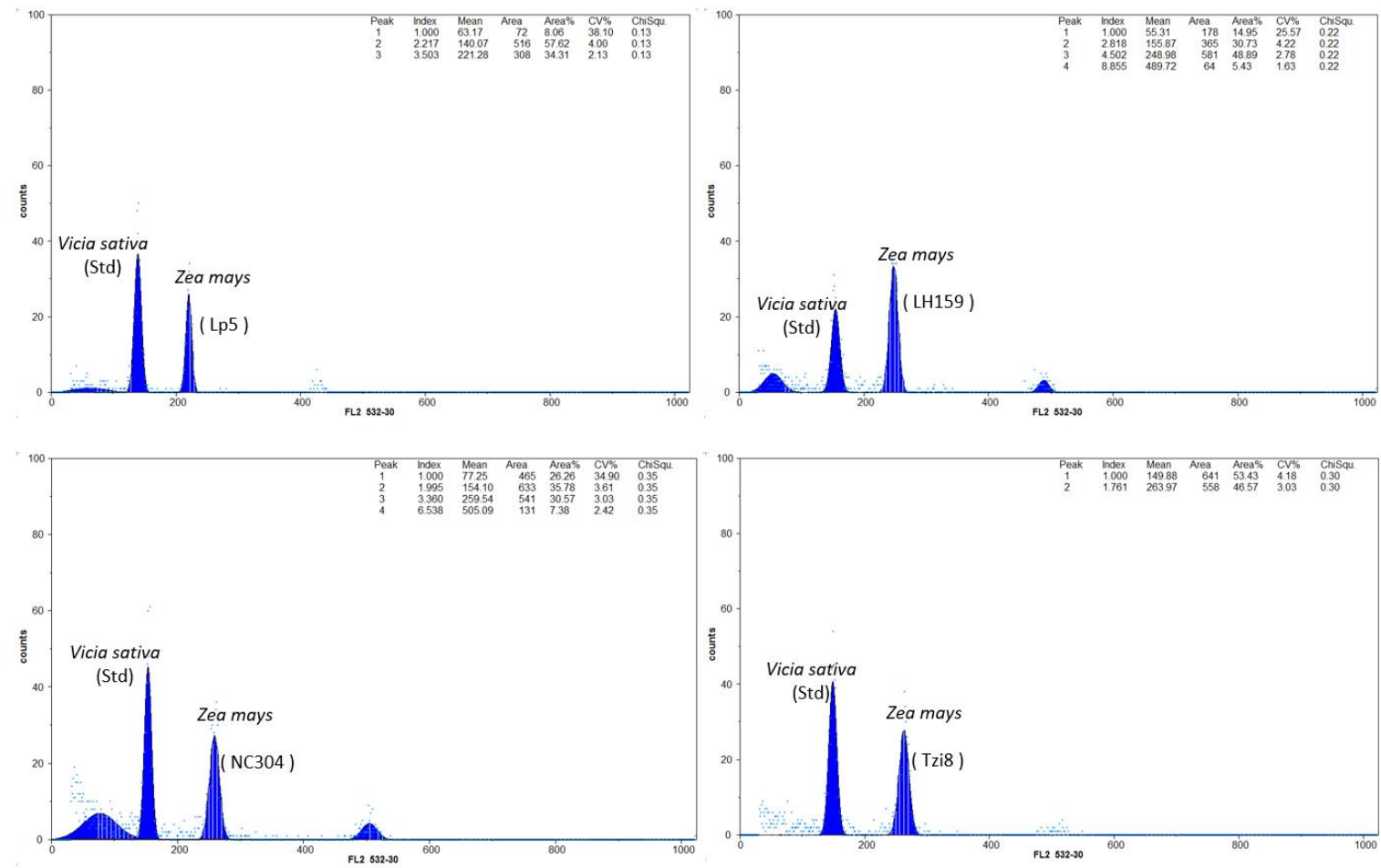

Figure 1. The results of DNA content variation in different genotypes using flow cytometry

To explore the relationship between DNA content and flowering time, Pearson's correlation coefficient analysis was performed (Figure 3). A highly significant and very positive correlation $(0.712 * *)$ was observed for DNA content and days to flowering. To offer a better understanding of the relationship between both variables, a regression analysis was also undertaken, which clearly discriminated the three groups (Figure 4) revealed that DNA content continued to increase with the increase in the number of days to flowering.

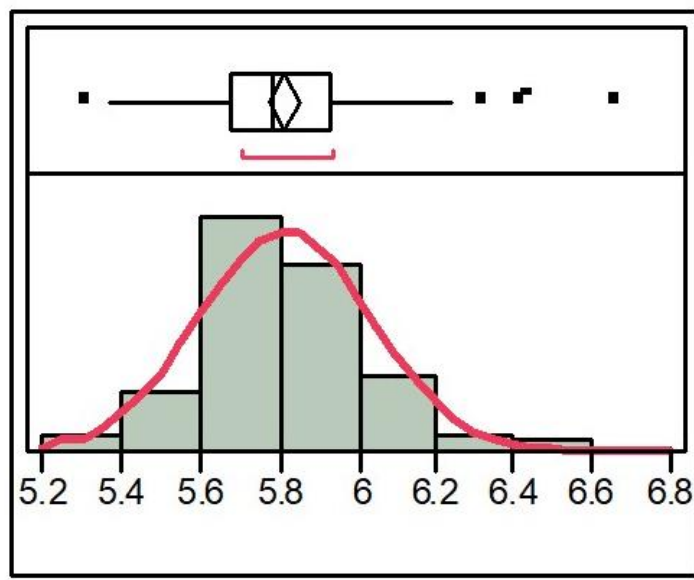

Figure 2. The distribution of DNA content of maize genotypes investigated in this study
Regression is an important statistical tool that allows identification and characterization of relationships between two or more factors (Schneider et al., 2010). Our regression analysis reflected a highly positive association between DNA content and days to flowering, confirming the results obtained from the correlation analysis (Figure 4). As the DNA content increased, the number of days to flowering also increased. The results of regression analysis also made a clear discrimination between the three groups having different flowering times.

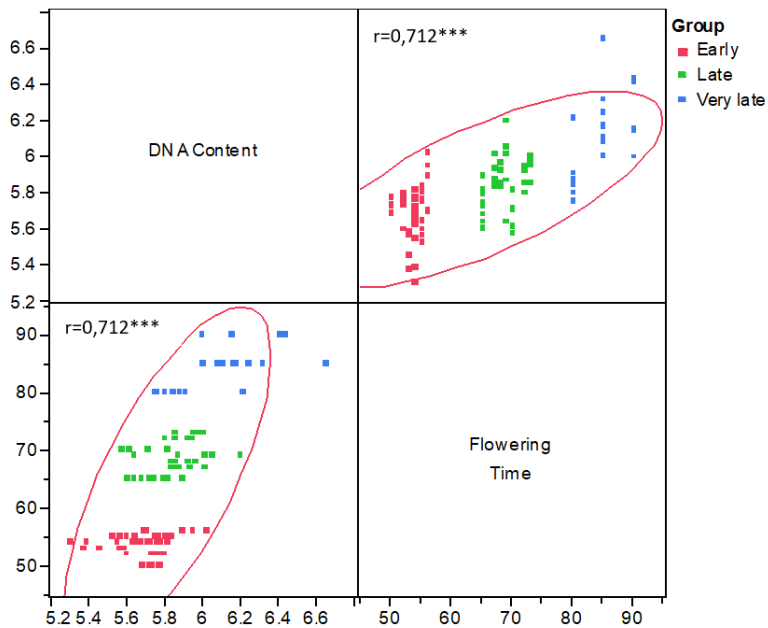

Figure 3. Correlation between DNA content and flowering time 


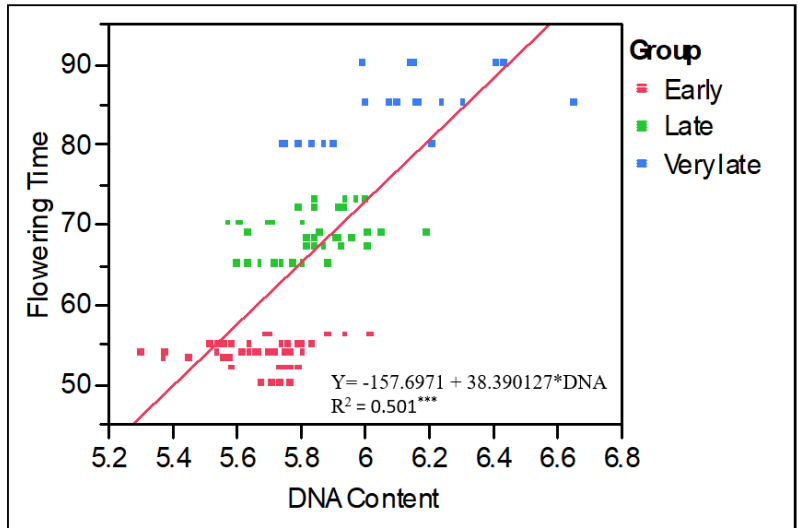

Figure 4. The results of regression analysis of DNA content and flowering time

\section{Discussion}

Crop improvement is an important approach that has remained the central focus of human beings to overcome challenges raised by biotic and abiotic stress. There is a need to boost breeding activities to mitigate these challenges by characterizing germplasm and identifying variations in DNA content. It has been proven that variation in DNA content differs from species to species and even within the same species. Earlier studies have confirmed that the phenotype of a plant is affected by the variation in the DNA content of that plant, and DNA content has been observed to affect seed size, vegetative growth, and flowering (Beaulieu et al., 2007; Tenaillon et al., 2016). Flowering time is considered an important character that plays a significant role in maize yield, and previous studies have revealed the correlation of this parameter with DNA content (Jian et al., 2017). Flowering time reflects the adaptation of a plant to its environment by tailoring its different growth stages according to the local climate. Researchers confirmed the presence of variation in flowering time in maize, ranging between 35 and 120 days (Colasanti et al., 2009). Alter et al. (2016) described the various factors affecting flowering time in maize. According to Díez et al. (2012), the DNA content of Zea changes within species, as well as between species. Changes in the DNA content are correlated with different phenotypic traits, such as seed size, growth rate, and flowering time (Beaulieu et al., 2007; Rayburn et al., 1994; Tenaillon et al., 2016).

In the current study, the accessions were grouped according to their flowering time, and all three groups reflected reasonable diversity in DNA content (Table 1). The mean DNA content of the early flowering group was $5.677 \pm 0.025 \mathrm{pg}$, and PHM81 was the inbred line with the highest DNA content. The late flowering group was diverse, containing both inbred lines and hybrids, and the average DNA content for this group was $5.835 \pm 0.027 \mathrm{pg}$. Among the three groups, the highest average of DNA content was determined in the very late flowering group containing inbred lines only. This study clearly reflected that DNA content continuously increased as the flowering time was delayed. Figure 2, presenting the distribution of DNA content in the three flowering groups, clearly reveals that most of the genotypes had a DNA content of around $5.8 \mathrm{pg}$. The range and average of DNA content obtained in this study were higher than previously reported (Rayburn et al., 1993; Jian et al., 2017). Furthermore, hybrid maize accessions had a higher DNA content than the early flowering group containing inbred lines only and most individuals in the late flowering group. A possible reason for this may be the higher vigor of hybrids as a result of heterosis. Inbred lines are obtained by recurrent selfing of the heterozygote material, and the two best performing inbred lines are crossed to create a hybrid cultivar. The average DNA content determined in this study was much higher than that obtained by Lee et al. (2002), who investigated eight inbred lines and eight maize hybrids. Such variations in the DNA content of maize have previously been attributed to the number and size of heterochromatic knobs (Jian et al., 2017; Lee et al., 2002). Repetitive sequences comprise $85 \%$ of genome, of which $9.4 \%$ is found in knobs (Piegu et al., 2006). Knobs are considered one of the major components of heterochromatic regions (Díez et al., 2013; Schnable et al., 2009). These variations in the DNA content of maize inbred lines can be associated with environmental factors and loss or gain of repetition in the genome which occurs during selection and selfing of inbred lines.

Correlation coefficient is the most important multivariate measure for assessing associations between various traits (Rana et al., 2015). In this analysis, if two traits have a significantly positive correlation, the selection of one trait will result in variation in the mean values of the associated trait through the additive gene effects of the selected individuals (Krasteva et al., 2008; Mudasir et al., 2012). Maize accessions used in this study were grouped separately according to their DNA content and days to flowering. A highly significant and positive correlation was observed between these two parameters, and the DNA content increased with the increasing in the number of days to flowering. The results of this study are in agreement with those reported by Jian et al. (2017), who revealed even a higher correlation between DNA content and days to flowering. The authors also stated that inbred lines obtained from a tropical region had higher DNA content compared to those from a temperate climate, as confirmed by our findings. Bilinski et al. (2018) and Rayburn et al. (1994) found a negative correlation between flowering time and DNA content. According to both studies, altitude/latitude is an important factor for flowering, and the DNA content of maize is lower due to its shorter life cycle. Our study provided different results compared to both studies because we used inbred lines and hybrids, rather than wild genotypes. Furthermore, Bilinski et al. (2018) and Rayburn et al. (1994) conducted their studies at higher altitude, which results in a shorter life cycle and lower DNA content, whereas the current study was conducted under near sea level conditions, increasing flowering time and ultimately leading to higher DNA content. Realini et al. (2016) stated that there was no correlation between DNA content and vegetative cycle of maize. Very recently, Akbudak et al. (2018) investigated the DNA content and its relationship with altitude for 
Turkish oat genotypes and found a negative correlation between these two variables. The authors utilized natural landraces and concluded landraces comprising huge human breeding efforts might have affected both DNA content and location of cultivation.

\section{CONCLUSIONS}

This study comprehensively investigated the level of variation in the DNA content of maize genotypes and revealed its positive association with days to flowering. From the results of the study, it was concluded that DNA content of maize plants can be used as a selection criterion for flowering time, which is an important characteristic for adaptation and agronomy in this crop.

\section{ACKNOWLEDGEMENTS}

I am very thankful to Prof. Dr. Metin Tuna for his laboratory assistance.

\section{LITERATURE CITED}

Akbudak, M.A., M. Sakiroglu and M. Tuna. 2018. Estimation of Nuclear DNA Content and Determination of Relationship Between Altitude and Genome Size of USDA Turkish Oat (Avena spp.) Collection. Gesunde Pflanzen.:1-8.

Alter, P., S. Bircheneder, L.Z. Zhou, U. Schlüter, M. Gahrtz, U. Sonnewald and T. Dresselhaus. 2016. Flowering Time Regulated Genes in Maize Include the transcription factor ZmMADS1. Plant physiology. pp-00285.

Bai, C., W.S. Alverson, A. Follansbee and D.M. Waller. 2012 New reports of nuclear DNA content for 407 vascular plant taxa from the United States. Annals of Botany. 110(8):16231629.

Beaulieu, J.M., A.T. Moles, I.J. Leitch, M.D. Bennett, J.B Dickie and C.A. Knight. 2007. Correlated evolution of genome size and seed mass. New Phytologist. 173(2):42237.

Bennett, M.D. and I.J. Leitch. 2011. Nuclear DNA amounts in angiosperms: targets, trends and tomorrow. Annals of Botany. 107(3):467-590.

Bennett, M.D. and I.J. Leitch. 1997. Nuclear DNA amounts in angiosperms - 583 new estimates. Annals of Botany. 80(2):169-96

Bennett, M.D. and IJ. Leitch. 2005. Nuclear DNA amounts in angiosperms: progress, problems and prospects. Annals of Botany. 95(1):45-90.

Bennett, M.D., P. Bhandol and I.J. Leitch. 2000.Nuclear DNA amounts in angiosperms and their modern uses - 807 new estimates. Annals of botany. 86(4):859-909.

Bennetzen, J.L. and E.A. Kellogg. 1997. Do plants have a oneway ticket to genomic obesity?. The Plant Cell. (9):1509.

Bilinski, P., P.S. Albert, J.J. Berg, J.A. Birchler, M.N. Grote, A. Lorant, J..Quezada, K. Swarts, J. Yang, J. Ross-Ibarra. 2018. Parallel altitudinal clines reveal trends in adaptive evolution of genome size in Zea mays. PLoS genetics. 14(5):e1007162.

Chung, J., J.H. Lee, K. Arumuganathan, G.L. Graef, J.E. Specht. 1998. Relationships between nuclear DNA content and seed and leaf size in soybean. Theoretical and Applied Genetics. 96(8):1064-8

Colasanti, J. and V. Coneva. 2009. Mechanisms of floral induction in grasses: something borrowed, something new. Plant Physiology. .149(1):56-62.

Devos, K.M., J.K. Brown, J.L. Bennetzen. 2002. Genome size reduction through illegitimate recombination counteracts genome expansion in Arabidopsis. Genome research. .12(7):1075-9.

Díez, C.M., B.S. Gaut, E. Meca, E. Scheinvar, S. MontesHernandez, L.E. Eguiarte, M.I. Tenaillon. 2013. Genome size variation in wild and cultivated maize along altitudinal gradients. New Phytologist. 199(1):264-76.

Díez, M.C., C. Vitte, J. Ross-Ibarra, B.S. Gaut, M.I. Tenaillon. 2012. Using nextgen sequencing to investigate genome size variation and transposable element content. InPlant transposable elements (pp. 41-58). Springer, Berlin, Heidelberg.

Fourastié, M.F., A.M. Gottlieb, L. Poggio, G.E. González. 2018. Are cytological parameters of maize landraces (Zea mays ssp. mays) adapted along an altitudinal cline?. Journal of plant research. 131(2):285-96.

Graham, M.J., C.D. Nickell, A.L. Rayburn. 1994. Relationship between genome size and maturity group in soybean. Theoretical and Applied Genetics. 88(3-4):429-32.

Greilhuber, J. and I.J. Leitch 2013.Genome size and the phenotype. InPlant Genome Diversity.2:. 323-344. Springer, Vienna.

Greilhuber, J., J. Doležel, M.A. Lysák, M.D. Bennett. 2005. The origin, evolution and proposed stabilization of the terms 'genome size' and 'C-value'to describe nuclear DNA contents. Annals of botany. 95(1):255-60.

Janoušek, V., L. Wang, K. Luzynski, P. Dufková, M.M. Vyskočilová, M.W. Nachman, P. Munclinger, M. Macholán, J. Piálek, P.K. Tucker. 2012. Genome-wide architecture of reproductive isolation in a naturally occurring hybrid zone between Mus musculus musculus and M. m. domesticus. Molecular Ecology. 21(12):3032-47.

Jian, Y., C. Xu, Z. Guo, S. Wang, Y. Xu, C. Zou. 2017. Maize (Zea mays L.) genome size indicated by 180-bp knob abundance is associated with flowering time. Scientific Reports. 7(1):5954.

Kidwell, M.G., D.R. Lisch. 2002.Transposable elements as sources of genomic variation. InMobile DNA II (pp. 59-90). American Society of Microbiology.

Knight, C.A., N.A. Molinari, D.A. Petrov. 2005. The large genome constraint hypothesis: evolution, ecology and phenotype. Annals of Botany. 95(1):177-90.

Lee, J.H., K. Arumuganathan, S.M. Kaeppler, S.W. Park, K.Y. Kim, Y.S. Chung, D.H. Kim, K. Fukui. 2002. Variability of chromosomal DNA contents in maize (Zea mays L.) inbred and hybrid lines. Planta. 215(4):666-71.

Leitch, A.R. and I.J. Leitch 2012. Ecological and genetic factors linked to contrasting genome dynamics in seed plants. New Phytologist. 194(3):629-46.

Leitch, I.J. and M.D. Bennett. 2007. Genome size and its uses: the impact of flow cytometry. Flow cytometry with plant cells: analysis of genes, chromosomes and genomes, ed. Dolezel, J., Greilhuber J., and Suda. J., pp. 153-176, WileyVCH Verlag GmbH \& Co. KGaA, Weinheim, Germany.

Li, Z., M. Zhu, J. Du, H. Ma, G. Jin, J. Dai. 2018. Genetic variants in nuclear DNA along with environmental factors modify mitochondrial DNA copy number: a populationbased exome-wide association study. BMC genomics. 19(1):752.

Ma, J., K.M. Devos, J.L. Bennetzen. 2004. Analyses of LTRretrotransposon structures reveal recent and rapid genomic DNA loss in rice. Genome Research. 14(5):860-869.

Meagher, T.R. and C. Vassiliadis. 2005. Phenotypic impacts of repetitive DNA in flowering plants. New Phytologist.168(1): 71-80.

Minelli, S., P. Moscariello, M. Ceccarelli, P.G. Cionini. 1996. Nucleotype and phenotype in Vicia faba. Heredity. 76(5): 524. 
Möller, M. 2018. Nuclear DNA C-values are correlated with pollen size at tetraploid but not diploid level and linked to phylogenetic descent in Streptocarpus (Gesneriaceae). South African Journal of Botany. 114: 323-44.

Mudasir, S., P.A. Sofi, M.N. Khan, N.R. Sofi, Z.A. Dar. 2012 Research article genetic diversity, variability and character association in local common Bean (Phaseolus vulgaris L.) germplasm of Kashmir. Electron J Plant Breed. (3): 883-91.

Nadeem, M.A., M.A. Nawaz, M.Q. Shahid, Y. Dogan, G. Comertpay, M. Yıldız, R. Hatipoglu, F. Ahmad, A. Alsaleh, N. Labhane, H. Ozkan, G. Chung and F.S. Baloch. 2017. DNA molecular markers in plant breeding: current status and recent advancements in genomic selection and genome editing. Biotechnol. Biotechnol. Equip. 32: 261-285.

Petrov, D.A. 2001. Evolution of genome size: new approaches to an old problem. TRENDS in Genetics. 17(1): 23-8.

Piegu, B., R. Guyot, N. Picault, A. Roulin, A. Saniyal, H. Kim, K. Collura, D.S. Brar, S. Jackson, R.A. Wing, O. Panaud. 2006. Doubling genome size without polyploidization: dynamics of retrotransposition-driven genomic expansions in Oryza australiensis, a wild relative of rice. Genome research 16(10): 1262-9.

Poggio, L., M. Rosato, A.M. Chiavarino, C.A. Naranjo. 1998. Genome size and environmental correlations in maize (Zea mays ssp. mays, Poaceae). Annal of Botany. 82(suppl_1): 107-15.

Rana, J.C., T.R. Sharma, R.K. Tyagi, R.K. Chahota, N.K. Gautam, M. Singh, P.N. Sharma, S.N. Ojha. 2015. Characterization of 4274 accessions of common bean (Phaseolus vulgaris L.) germplasm conserved in the Indian gene bank for phenological, morphological and agricultural traits. Euphytica 205(2): 441-57.

Rayburn, A.L., D.P. Biradar, D.G. Bullock, L.M. McMurphy. 1993. Nuclear DNA content in F 1 hybrids of maize. Heredity. 70(3): 294.
Rayburn, A.L., J.W. Dudley, D.P. Biradar. 1994. Selection for early flowering results in simultaneous selection for reduced nuclear DNA content in maize. Plant Breeding. 112(4): 31822.

Realini, M.F., L. Poggio, J. Cámara-Hernández, G.E. González. 2016. Intra-specific variation in genome size in maize: cytological and phenotypic correlates. AoB Plants. 8.

SanMiguel, P., A. Tikhonov, Y.K. Jin, N. Motchoulskaia, D. Zakharov, A. Melake-Berhan, P.S. Springer, K.J. Edwards M. Lee, Z. Avramova, J.L. Bennetzen. 1996. Nested retrotransposons in the intergenic regions of the maize genome. Science. 274(5288): 765-8.

Schnable, P.S., D. Ware, R.S. Fulton, J.C. Stein, F. Wei, S. Pasternak, C. Liang, J. Zhang, L. Fulton, T.A. Graves, P. Minx. 2009. The B73 maize genome: complexity, diversity, and dynamics. science. 326(5956): 1112-5.

Schneider, A., G. Hommel, M. Blettner. 2010. Linear regression analysis: part 14 of a series on evaluation of scientific publications. Deutsches Ärzteblatt International. 107(44): 776.

Tenaillon, M.I., D. Manicacci, S.D. Nicolas, F. Tardieu, C. Welcker. 2016. Testing the link between genome size and growth rate in maize. PeerJ. 4:e2408.

Wendel, J.F., R.C. Cronn, I. Alvarez, B. Liu, R.L. Small, D.S. Senchina. 2002. Intron size and genome size in plants. Molecular biology and evolution. (12): 2346-52.

Wessler, S.R. 2006. Transposable elements and the evolution of eukaryotic genomes. Proceedings of the National Academy of Sciences 103(47): 17600-1.

Zonneveld, B.J., I.J. Leitch, M.D. Bennett. 2005. First nuclear DNA amounts in more than 300 angiosperms. Annals of botany. 96(2): 229-44. 